DOI: https://doi.org/10.15407/publishing2020.55.058

\title{
RETURN-ROTARY MOTION CONTROL SYSTEM OF ROTOR OF BRUSHLESS MAGNETOELECTRIC MOTOR
}

\author{
K.P. Akinin*, A.E. Antonov**, V.G. Kireyev***, A.A. Filomenko**** \\ Institute of Electrodynamics of the National Academy of Sciences of Ukraine, \\ pr. Peremohy, 56, Kyiv, 03057, Ukraine \\ e-mail: aoe@ied.org.ua
}

A subject of this paper is a development of the system of control by return-rotary motion of rotor of brushless magnetoelectric motor. In the paper we studied a method for calculating a control system of the rotation angle amplitude of the rotor shaft by specifying the phase stability margin based on the frequency characteristics of an open-loop system. A calculation of the loop of the current effective value of stator windings is carried out on the basis of a given limitation accuracy. Using the obtained analytical dependences allows us to automatically calculate the controller parameters depending on the frequency of mechanical vibrations of the rotor shaft in a given operating range. In the paper we provide the examples of transient responses for controlling the rotation angle amplitude and current effective value at the motor start and mechanical load changes. Reference 9, figure 5, table 3.

Key words: brushless magnetoelectric motor, return-rotary motion, control system, carrier frequency, frequency characteristic.

Introduction. Generation of the paths of return-rotary motion (RRM) of an actuating element is one of the problems arising during the development of electric drives. The electromechanical systems, in which the actuators perform the RRM, include technological and medical equipment, devices for special machinery and other.

An implementation of electromechanical systems of the RRM can be based on different physical principles, e.g., using special mechanical transmissions $[1,2]$, electric drives based on induction motors [3], or doubly-fed motors [4].

In this paper we considered a structure of electric drive based on a special brushless magnetoelectric motor (BMM) without the use of any transmission mechanisms [5]. In this case, an actuating element of the device is installed directly on a motor shaft, so that it is possible to directly control frequency and amplitude of the mechanical oscillations by acting on a stator winding. Therefore, the important problem is to control by RRM with the given performance indexes.

The purpose of the paper is to develop a system for controlling the RRM path of BMM with a given amplitude of the rotation angle of the rotor subject to the limitation of the stator current effective value.

The main material and research results. BMM for $\mathrm{RRM}$ is an electromechanical system in which alternating voltage of the stator is an input action, and the amplitude of rotor oscillations is an output parameter. The previous research [Paper] showed a nonlinear dependence of the input and output parameters of the system. Thus, stabilization of the amplitude of the rotor's rotation angle is possible in the range of a carrier frequency of oscillations $f_{O}$ up to $25-30 \mathrm{~Hz}$. In a high-frequency part of the range, it is necessary to limit stator current effective value at a given level. The output parameters are: an amplitude of the rotor's rotation angle and the stator current effective value can be determined on each one-half period of the stator alternating voltage, while the obtained values are stored as feedback signals during the next one-half periods. The latter circumstance determines a time delay effect in a control system loop. Since the BMM operates in the range of the carrier frequency $f_{O}$ from 5 to $50 \mathrm{~Hz}$, the parameters of the control system should be tuned taking into account the changing frequency values. There are no special requirements for the accuracy and speed of response of the controlled parameters.

The BMM for RRM is a structure consisting of a slotless stator with winding, an external magnetic circuit and additional permanent magnet for realizing the effect of a magnetic spring, as

(C) Akinin K.P., Antonov A.E., Kyreyev V.G., Filomenko A.A., 2020

ORCID ID:* https://orcid.org/0000-0002-7830-2311, ** https://orcid.org/0000-0001-8952-8327,

***https://orcid.org/0000-0002-9407-1074, **** https://orcid.org/0000-0003-4289-8579 
well as rotor on bearing assembly with a two-pole permanent magnet and actuating element mounted on its shaft [5]. A mathematical model of such motor is described by the following equations [6]:

$$
\begin{gathered}
L \frac{d i}{d t}=-R i-k_{m} \omega \cos \alpha+u ; \\
M=k_{m} i \cos \alpha ; \\
M_{\omega}=k_{\omega} \omega ; \\
M_{\alpha}=k_{\alpha} \sin \alpha ; \\
J \frac{d \omega}{d t}=M-M_{\omega}-M_{\alpha}-M_{R}-M_{L} ; \\
\frac{d \alpha}{d t}=\omega,
\end{gathered}
$$

where $\omega, \alpha$ - angular speed and rotation angle of the rotor shaft; $L, R$ - inductance and active resistance of the stator winding; $i, u$-current and stator control voltage; $k_{m}$ - torque coefficient; $J$ - rotor inertia; $M_{\omega}, M_{\alpha}, M_{R}, M_{L}$ - torques of viscous friction and elasticity, reactive torque of bearings and the torque of load, respectively; $k_{\omega}, k_{\alpha}$ - viscosity and elasticity coefficients. The reactive torque of bearings is determined according to the equation $M_{R}=M_{B} \operatorname{sign}(\omega)$, where $M_{B}-$ bearing friction torque. Also, we assume the following dependence for setting the load torque $M_{L}=k_{L} \omega$, where $k_{L}-$ viscosity coefficient of the motor load.

A structure of BMM with a voltage modulator that operates at the carrier frequency $f_{O}$ is shown in Fig. 1 , where $U_{A}$ - stator voltage amplitude; $x_{O}\left(\omega_{O} t\right)$ - periodic carrier signal, where $\omega_{O}=2 \pi f_{O} ; \alpha_{A}, I-$

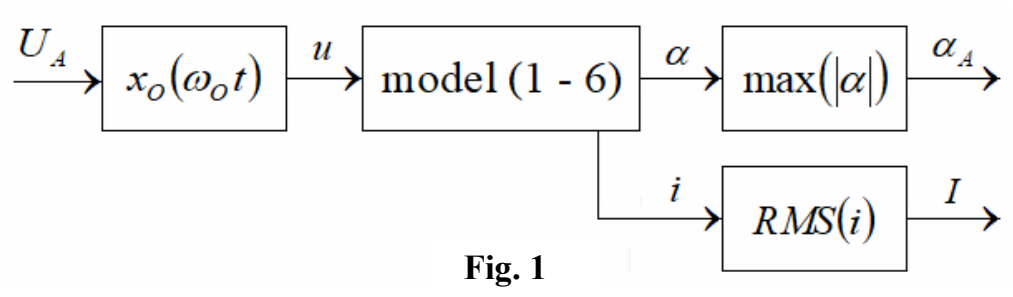
amplitude of the rotation angle of the rotor shaft and the stator current effective value; $\max (|\alpha|), \operatorname{RMS}(i)$ - procedures for determining an amplitude of the module of rotation angle of the rotor shaft and stator current effective value at each one-half of the stator alternating voltage.

In this research, we assume that the carrier periodic signal has a sinusoidal shape $x_{O}(t)=\sin \omega_{O} t$. In this case, the stator voltage is defined as

$$
u=U_{A} \sin \omega_{O} t \text {. }
$$

The elements of the theory of automatic control systems (ACS) at the carrier frequency were developed back in the 60 s of the XX century for structures containing sensors and actuating motors of AC current [7].

In our case, parameters of the controller of the rotation angle amplitude can be chosen by using amplitude and phase frequency characteristics of an open-loop system, which can be represented as

$$
\begin{gathered}
A_{S}(\omega)=A_{C}(\omega) A_{\alpha}(\omega) ; \\
\varphi_{S}(\omega)=\varphi_{C}(\omega)+\varphi_{\alpha}(\omega),
\end{gathered}
$$

where $A_{P}(\omega), A_{\alpha}(\omega), \varphi_{P}(\omega), \varphi_{\alpha}(\omega)$ - amplitude and phase frequency characteristics of the controller and BMM.

To study the BMM properties, an amplitude-modulated signal is fed to an input of the system (Fig. 1) $U_{A}(t)=x(t)$, where $x(t)=1+a \sin \Omega t$ - modulating signal; $a=0,5 ; \Omega=\frac{\omega_{O}}{n} ; n \geq 2$ 
- whole number. Wherein, the variable values of the rotation angle $\alpha$ and the stator current $i$ are modulated output variable signals. As a result of the $\max (|\alpha|)$ and $\operatorname{RMS}(i)$ procedures, we have

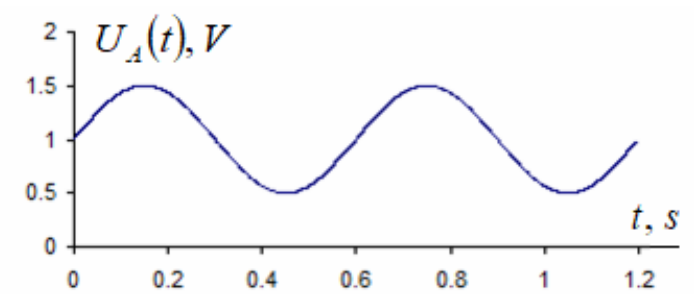

demodulated signals $\alpha_{A}$ and $I$, discreetly repeating the envelopes of $\alpha$ and $i$ variables. The researches have shown that a modulus of an amplitude frequency characteristic of the envelope of the output signal $\alpha_{A}$ with an accuracy of no worse than $7 \%$ corresponds to the dependence of the rotation angle amplitude on the frequency of linearized system of equations (1)-(6) under

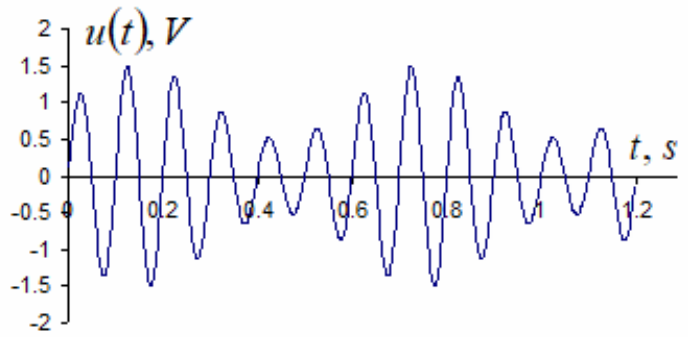
$M_{P}=0$ conditions, as well as $\cos \alpha=1$ and $\sin \alpha=\alpha$, which is acceptable for $\alpha_{A}<\frac{\pi}{6}$. The phase shift of the variable quantized signal $\alpha_{A}$ relative to a given envelope $x(t)$ is approximately determined by the formula

$$
\varphi=\frac{\pi}{n} .
$$
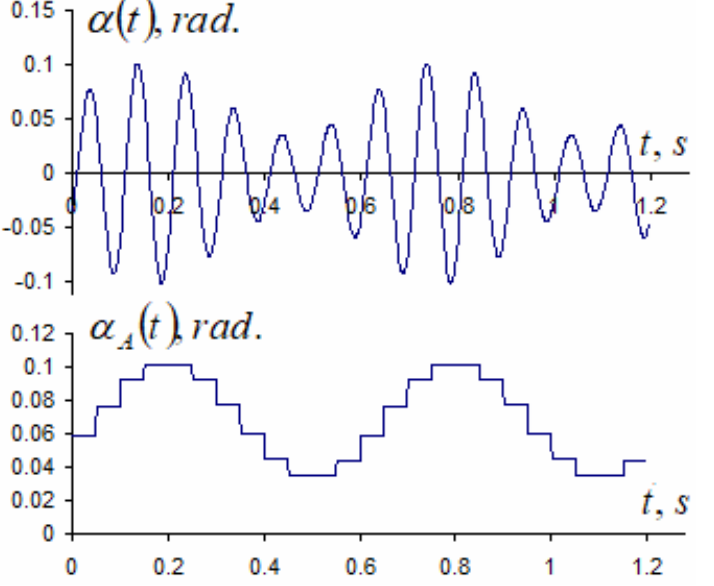

Fig. 2 $u(t), \alpha(t)$, and $\alpha_{A}(t)$ at $f_{O}=10 \mathrm{~Hz}$ and $n=6$.

The dependences of the amplitude of the rotation angle $\alpha$ and the amplitude of current $i$ on the frequency for linearized system of equations (1)-(6) can be defined as

$$
\begin{aligned}
& A_{\alpha}(\omega)=\frac{k_{1}}{\sqrt{\left(1-b_{2} \omega^{2}\right)^{2}+\omega^{2}\left(b_{1}-b_{3} \omega^{2}\right)^{2}}} ; \\
& A_{i}(\omega)=\frac{\sqrt{B_{1}^{2}(\omega)+B_{2}^{2}(\omega)}}{R\left(\left(1-b_{2} \omega^{2}\right)^{2}+\omega^{2}\left(b_{1}-b_{3} \omega^{2}\right)^{2}\right)},
\end{aligned}
$$

where $\quad k_{1}=\frac{k_{m}}{R k_{\alpha}} ; \quad b_{1}=\frac{L}{R}+\frac{k_{\omega}}{k_{\alpha}}+\frac{k_{m}^{2}}{R k_{\alpha}} ; \quad b_{2}=\frac{J}{k_{\alpha}}+\frac{L k_{\omega}}{R k_{\alpha}} ; \quad b_{3}=\frac{L J}{R k_{\alpha}} ; \quad b_{4}=\frac{k_{\omega}}{k_{\alpha}} ; \quad b_{5}=\frac{J}{k_{\alpha}} ;$ $B_{1}(\omega)=\left(1-b_{5} \omega^{2}\right)\left(1-b_{2} \omega^{2}\right)+b_{4} \omega^{2}\left(b_{1}-b_{3} \omega^{2}\right) ; B_{2}(\omega)=b_{4} \omega\left(1-b_{2} \omega^{2}\right)-\omega\left(1-b_{5} \omega^{2}\right)\left(b_{1}-b_{3} \omega^{2}\right)$.

The ACS of the angle amplitude can be implemented on the basis of an integral controller (I-controller), which has an amplitude and phase frequency characteristic of the form

$$
\begin{gathered}
A_{C}(\omega)=\frac{k_{C}}{\omega} ; \\
\varphi_{C}(\omega)=-\frac{\pi}{2},
\end{gathered}
$$

where $k_{C}$ - amplification factor of I-controller of the amplitude of rotation angle.

A choice of the value of the transmission factor of controller based on the frequency characteristics can be carried out provided that the specified phase stability margin $\gamma$ is determined, which is defined by formula

$$
\gamma=\pi+\varphi_{C}\left(\omega_{C}\right)+\varphi\left(\omega_{C}\right)
$$

where $\omega_{C}=\frac{\omega_{O}}{n}$ - cut-off frequency, the value of which is less than the carrier frequency $\omega_{O}$. 
At a given value of the phase stability margin $\gamma$, the Icontroller amplification coefficient $k_{P И}$ is determined provided that an amplitude frequency characteristic of the open-loop system is equal to unity

\begin{tabular}{|c|c|c|c|c|c|c|}
\hline$N$ & $n$ & $\varphi$, el. grad. & $\gamma$, el. grad. & $k_{C}$, V $/$ rad. & $t_{C}, s$ & $\sigma, \%$ \\
\hline 1 & 3 & 60 & 30 & 307 & 0,10 & 35,0 \\
2 & 4 & 45 & 45 & 230 & 0,10 & 21,5 \\
3 & 5 & 36 & 54 & 184 & 0,15 & 11,2 \\
4 & 6 & 30 & 60 & 154 & 0,15 & 5,0 \\
5 & 8 & 22,5 & 67,5 & 115 & 0,25 & 0,2 \\
6 & 10 & 18 & 72 & 92,1 & 0,35 & 0,0 \\
7 & 12 & 15 & 75 & 77,8 & 0,45 & 0,0 \\
8 & 15 & 12 & 78 & 61,4 & 0,60 & 0,0 \\
\hline
\end{tabular}
( $A_{S}(\omega)=1$ ) at the cut-off frequency $\omega_{C}$ according to the formula

$$
k_{C}=\frac{\omega_{C}}{A_{\alpha}\left(\omega_{C}\right)} \text {. }
$$

Table 1 shows the calculating results of the I-controller parameters of the rotation angle amplitude and performance indexes of the transient response of output signal $\alpha_{A}$ of the closed loop system, which consists of the controller and BMM (Fig. 1) with a step input signal and the value of

\begin{tabular}{|c|c|c|c|c|c|}
\hline$N$ & $f_{O}, H z$ & $n$ & $k_{C}, V / r a d$. & $t_{C}, s$ & $\sigma, \%$ \\
\hline 9 & 5 & 4 & 113 & 0,2 & 12,5 \\
10 & & 6 & 74,4 & 0,4 & 3,5 \\
11 & & 8 & 56,3 & 0,5 & 0,0 \\
12 & & 10 & 45,1 & 0,8 & 0,0 \\
\hline 13 & 20 & 4 & 581 & 0,05 & 24,8 \\
14 & & 6 & 389 & 0,075 & 6,7 \\
15 & & 8 & 290 & 0,125 & 0,5 \\
16 & & 10 & 232 & 0,175 & 0,0 \\
\hline 17 & 30 & 4 & 1403 & 0,0333 & 23,0 \\
18 & & 6 & 939 & 0,0667 & 5,1 \\
19 & & 8 & 701 & 0,1 & 3,6 \\
20 & & 10 & 562 & 0,1667 & 1,6 \\
\hline
\end{tabular}
carrier frequency $f_{O}=10 \mathrm{~Hz}$, where

$t_{C}$ is a control time determined by a time at which the output signal reaches a five percent zone from the steady-state value; $\sigma$ is an overshooting as a relative value of the maximum deviation of the output signal; $N$ is a number of the calculation option.

Table 2 shows the same parameters but for the other frequency values. The presented data confirm a possibility of calculating the controller according to formulas (10-16) in the frequency range from 5 to $30 \mathrm{~Hz}$. At the same time, we can note the differences in the performance indexes of transient responses at different frequencies, which can be explained by insufficiently accurate determination of the phase angle $\varphi(10)$, as well as signal distortions $\alpha_{A}(t)$ at the carrier frequency of about $30 \mathrm{~Hz}$.

The speed of controlling the rotation angle amplitude in the range of the carrier frequency from 5 to $10 \mathrm{~Hz}$ can be increased by using a proportional-integral controller (PI-controller), which has an amplitude and phase-frequency characteristic of the form

$$
\begin{array}{r}
A_{C}(\omega)=\frac{k_{C}}{\omega} \sqrt{1+T_{C}^{2} \omega^{2}} ; \\
\varphi_{C}(\omega)=-\frac{\pi}{2}+\operatorname{arctg} T_{C} \omega,
\end{array}
$$

where $k_{C}, T_{C}$ - amplification factor and time constant.

In this case the controller parameters are determined as

$$
\begin{gathered}
T_{C}=\frac{1}{\omega_{C}} \operatorname{tg}\left(\gamma-\frac{\pi}{2}+\varphi\left(\omega_{C}\right)\right), \\
k_{C}=\frac{\omega_{C}}{A_{\alpha}\left(\omega_{C}\right) \sqrt{1+T_{C}^{2} \omega_{C}^{2}}} .
\end{gathered}
$$




\begin{tabular}{|c|c|c|c|c|c|c|c|}
\hline$N$ & $n$ & $\varphi$, el.grad. & $\gamma$, el.grad. & $k_{C}$, V $/$ rad. & $T_{P}, s$ & $t_{C}, s$ & $\sigma, \%$ \\
\hline 21 & 3 & 60 & 45 & 297 & 0,01279 & 0,1 & 15,4 \\
22 & 3 & 60 & 60 & 266 & 0,02757 & 0,15 & 0,0 \\
23 & 4 & 45 & 60 & 222,5 & 0,01706 & 0,1 & 3.0 \\
\hline
\end{tabular}

Table 3 shows the calculation results of the PI-controller parameters of the rotation angle amplitude and quality indicators of the transient response of the control at a value of the carrier frequency $f_{O}=10 \mathrm{~Hz}$.

Fig. 3 shows the graphs of transient responses for the calculation options $a-4, b-6, c-8$, $d-11, e-15, f-19, g-21, h-22, i-23$, respectively.

The presented data show satisfactory results in a low-frequency region of the control range. At the same time, the researches showed difficulties in tuning PI-controller in the region of carrier frequencies close to $30 \mathrm{~Hz}$. However, his is not a problem, since a dynamics of the processes with the I-controller in this frequency range is quite acceptable.
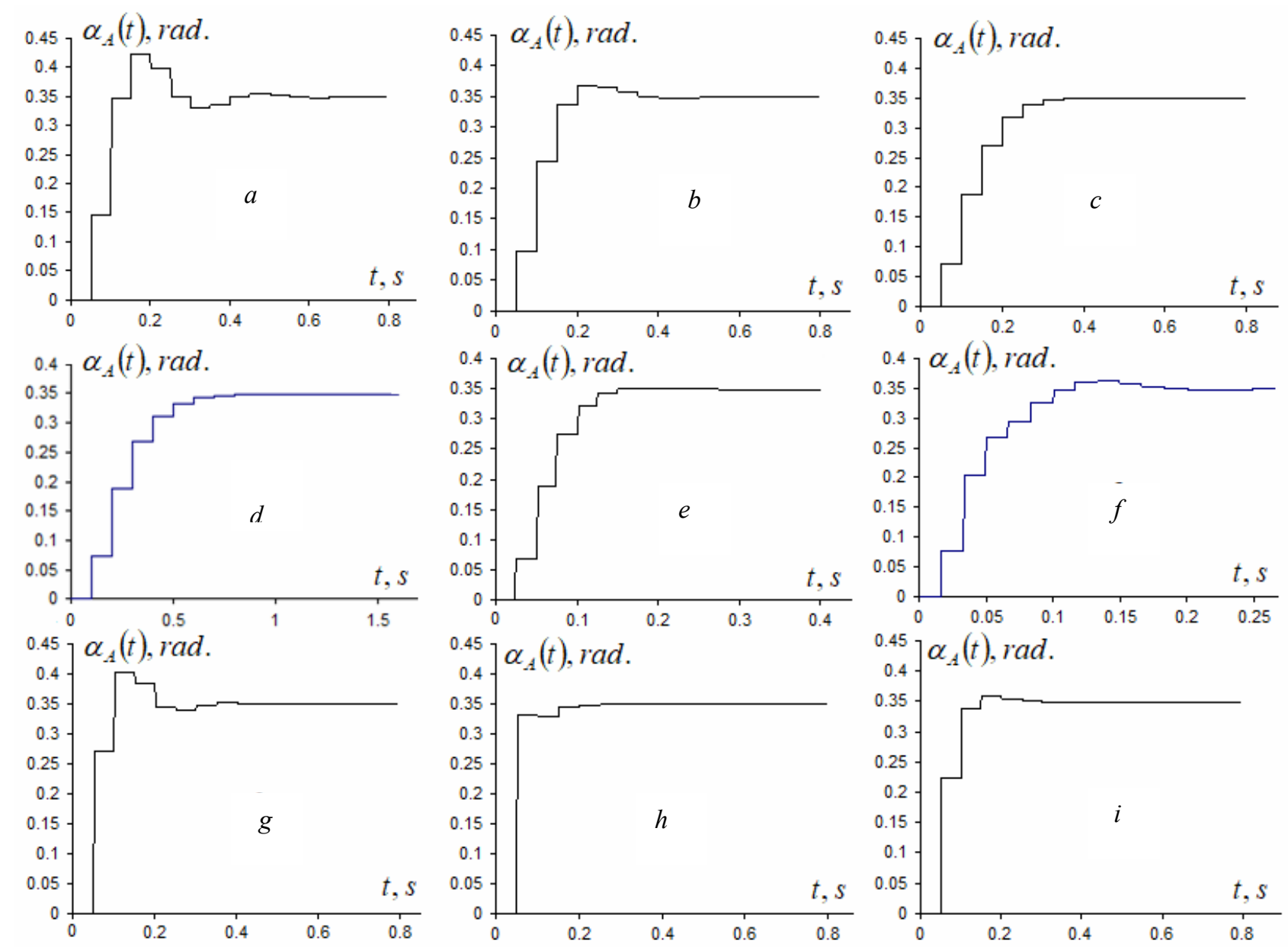

Fig. 3

A second function of the BMM control system is a current limit of the stator winding in the range of carrier frequency of more than $30 \mathrm{~Hz}$. To implement this function, an additional closed loop with a nonlinearity is introduced into the system [8], like

$$
x_{2}=0 \text { if } I<I_{O}
$$

or

$$
x_{2}=I-I_{O} \text { if } I>I_{O},
$$


where $I_{O}-$ a task at which current starts to be limited. In addition, a lowfrequency filter is introduced into the closed loop of the current limit.

Thus, we can present a final structure of BMM control system, which is shown in Fig. 4,

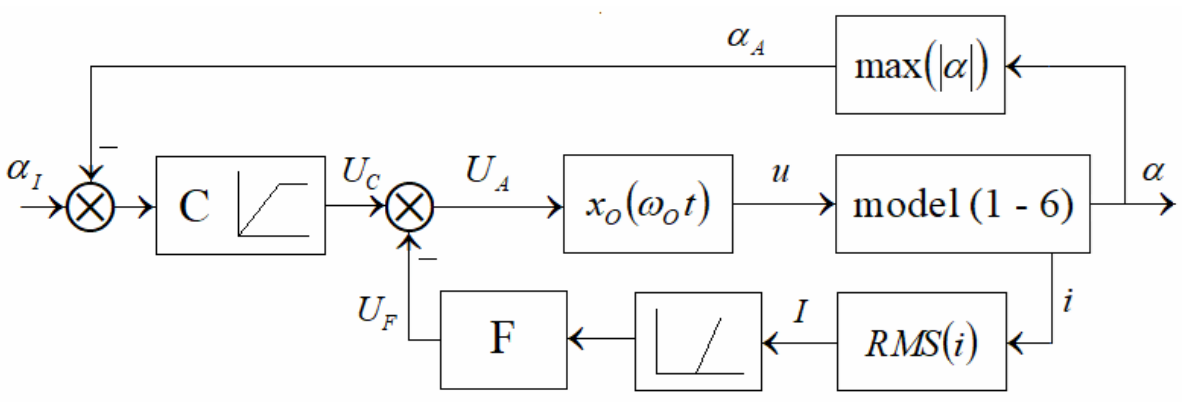
where $\mathrm{R}-$ is a regulator of

Fig. 4 the rotation angle amplitude with a saturation nonlinearity; $\mathrm{F}-$ is a filter.

Below there are equations of the amplitude I-controller with a saturation and low-frequency filter

$$
\begin{gathered}
U_{C}(m)=U_{C}(m-1)+\left(\alpha_{I}-\alpha_{A}\right) k_{C} h ; \\
U_{C}(m)=U_{\max } \text { if } U_{C}(m)>U_{\max } ; \\
U_{F}(m)=U_{F}(m-1)+\left(x_{2}-U_{F}(m-1)\right) k_{F} \frac{h}{T_{F}} ; \\
U_{A}=U_{C}-U_{F},
\end{gathered}
$$

where $U_{C}$ - output signal of the controller; $\alpha_{I}$ - input signal of the system; $U_{\max }$ - maximum value of the controller output signal; $m$ - number of an integration step; $h$-integration step; $U_{F}$ - output signal of the filter; $k_{F}, T_{F}$ - amplification factor and time constant of the filter.

The equations of the PI-controller with a saturation are [9]

$$
\begin{gathered}
U_{P}=\left(\alpha_{I}-\alpha_{A}\right) k_{R} T_{R} \text { if } U_{P}<U_{\max } \text { or } U_{P}=U_{\max } \text { if } U_{P}>U_{\max } \\
U_{I}(m)=U_{I}(m-1)+\left(\alpha_{I}-\alpha_{A}\right) k_{R} h \text { if } U_{I}<U_{\max }-U_{P} ; \\
U_{I}(m)=U_{\max }-U_{P} \text { if } U_{I}>U_{\max }-U_{P} ; \\
U_{C}=U_{P}+U_{I}
\end{gathered}
$$

where $U_{P}, U_{I}$ - proportional and integral components of the PI-controller output signal.

A calculation of the filter transmission factor in the current limitation loop is carried out under the condition of ensuring a specified accuracy of the current limitation. Based on the condition (13) and taking into account a frequency characteristic $A_{i}(\omega)(12)$, we have the following formula for a steady state mode of the current limitation

$$
k_{F}=\frac{A_{i}\left(\omega_{O}\right) U_{\max }-\sqrt{2} I}{A_{i}\left(\omega_{O}\right)\left(I-I_{O}\right)} .
$$

Coefficient $\sqrt{2}$ was introduced in the formula since an amplitude of the sinusoidal current is $\sqrt{2}$ times greater than the effective value of the current.

The time constant $T_{F}$ is determined under the condition of excluding possible current fluctuations due to the discrete nature of the signal $I$ as

$$
T_{F}=\frac{20}{f_{O}}
$$

Since the current limitation mode is carried out only in a high-frequency part of the operating range, an introduction of the filter with such value of time constant does not lead to a deterioration of the transient performance.

When calculating the RRM processes, we assume that viscosity coefficient of the motor load $k_{L}$ changes in accordance with the equation 

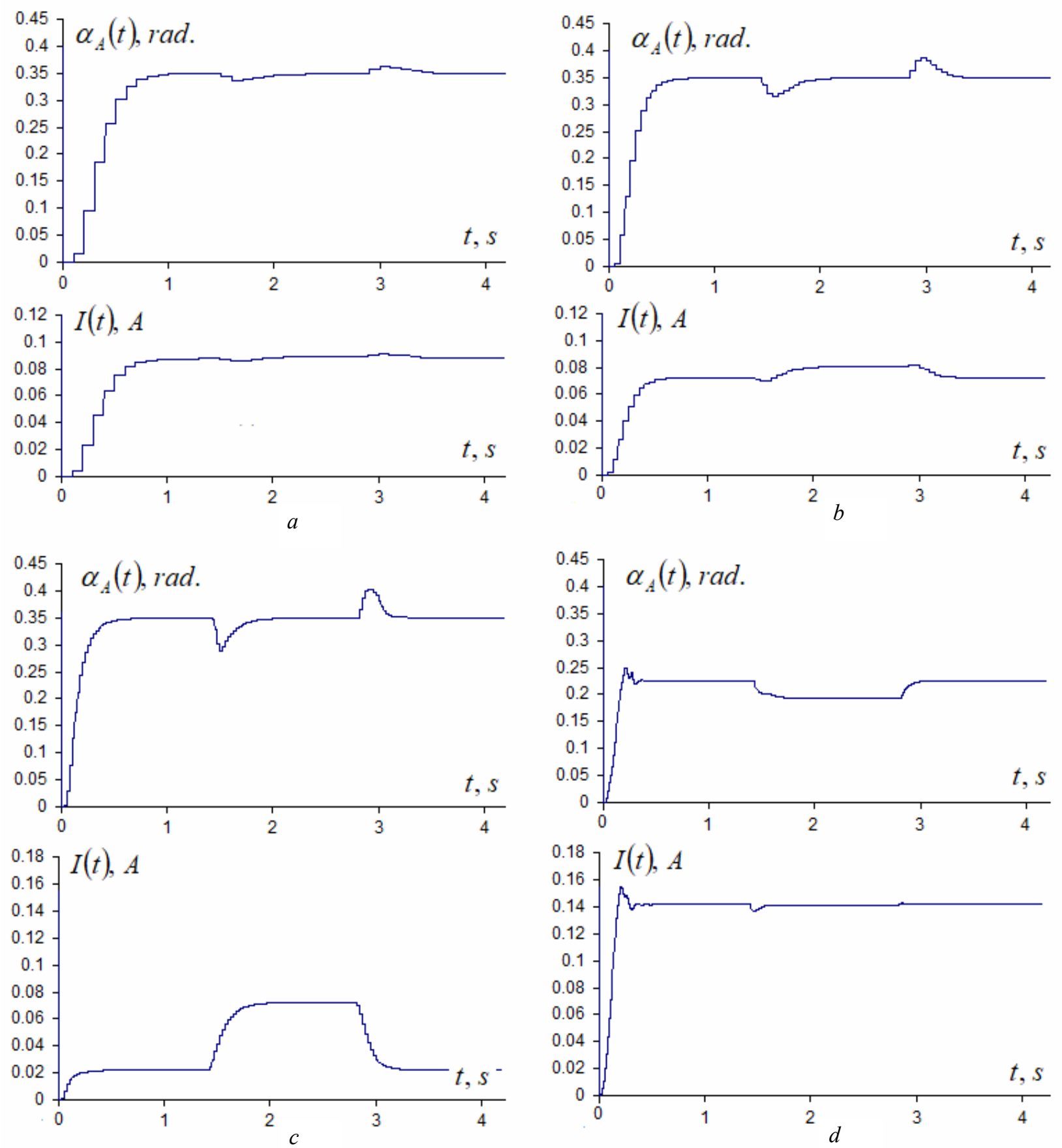

Fig. 5

$$
T_{L} \frac{d k_{L}}{d t}=k_{R}-k_{L}
$$

when the reference load coefficient $k_{R}$ changes stepwise, where $T_{L}=0,1 s$ - time constant. Moreover, to ensure a smooth start of the BMM, a response time of the reference signal change is introduced

$$
\alpha_{I}(m)=\alpha_{I}(m-1)\left(1-\frac{h}{T_{2}}\right)+\alpha_{R} \frac{h}{T_{2}},
$$

where $\alpha_{R}$-reference signal; $T_{2}=0,1 s$ - time constant.

To show the BMM operation in RMM mode, we calculated the dynamics of regulation with I-controller at the motor start and the load parameter stepwise change $k_{R}$ from zero to the maximum value and back to zero. The dynamics was calculated using the formulas $(1-7,21-26,33,34)$ 
for such values of the system parameters - L=0,012 Hz, R=40 Ohm, $k_{m}=0,125 \mathrm{Nm} / \mathrm{A}$, $J=2,4 \cdot 10^{-6} \mathrm{~kg} \mathrm{~m}{ }^{2}, \quad k_{\omega}=6,5 \cdot 10^{-5} \mathrm{Nms} / \mathrm{rad} ., \quad k_{\alpha}=0,0448 \mathrm{Nm} / \mathrm{rad} ., \quad M_{G}=2 \cdot 10^{-4} \mathrm{Nm}$, $\alpha_{R}=\frac{\pi}{9} \mathrm{rad} ., \quad U_{\max }=15 \mathrm{~V}, \quad I_{O}=0,14 \mathrm{~A}$. The maximum value of $k_{R}$ coefficient is $2,1 \cdot 10^{-4} \mathrm{Nm} \mathrm{s} / \mathrm{rad}$.

The values of system parameters depending on the carrier frequency $f_{O}$ were calculated by formulas $(11,13-16,31,32)$ at $n=8$.

Fig. $5(a-d)$ shows the graphs of transient responses of the rotation angle amplitude change $\alpha_{A}$ and current effective value $I$ at the carrier frequencies $f_{O}$ of $5(a), 10(b), 20(c)$, and $40(d)$ $\mathrm{Hz}$ in the modes of motor start and load changes. When $f_{O}=40 \mathrm{~Hz}$ and a given accuracy of current limitation is $1 \%$, the filter parameters in the current limitation loop have the following values $k_{F}=2692 \mathrm{~V} / \mathrm{A}$ and $T_{F}=0,5 \mathrm{~s}$. In the current limitation mode in the frequency range of more than $30 \mathrm{~Hz}$, the value of controller parameters of the angle amplitude is stored as it was at this frequency value. At the same time, in the stabilization mode of rotation angle amplitude, the values of filter parameters do not matter.

Conclusion. 1. The researches have confirmed the possibility of an analytical calculation of the controller parameters of rotation angle amplitude of the motor rotor during the RRM by setting a value of the phase stability margin.

2. A structure of the control system allows a transition from the stabilization mode of the rotation angle amplitude of the rotor to the mode of limiting the stator current effective value, which is possible due to the introduction of nonlinearity and low-frequency filter into additional current closed loop.

3. Using the obtained analytical dependencies allows us to automatically calculate the parameters of the controller and filter depending on the value of carrier frequency in a given operating range. In the case of non-sinusoidal carrier periodic signal formation, it is necessary to obtain amplitude frequency characteristics of the open-loop system by means of calculation based on the system of equations (1-6).

Фінансується за держбюджетною темою «Створити методи активної компенсації реактивних зусиль, моментів та просторових переміщень в електромеханічних системах магнітоелектричного типу та розробити приниипи побудови пристроїв на їх основі» (шифр «ІНДЕМ»), щуо виконується за Постановою Бюро ВФТПЕ 15.10.2013 р., протокол № 14. Державний реєстрачійний номер роботи $0113 U 006532$.

1. Smeliahin A.Y. The structure of mechanisms and machines. Moskva: Vysshaia shk., 2006. 304 p. (Rus)

2. Yusofl A.S., Che-Ani A.I., Hussain Z., Hmzah N., Boudvill R., Rahman M.F.A. Back-Drivability of Powered Knee Free Swing and Knee Extension. 7th IEEE International Conference on Control System. Computing and Engineering (ICCSCE 2017). 24-26 November 2017. Penang. Malaisia. Pp. 331-335.

3. Lukovnikov V.Y. Electric drive of oscillatory motion. Moskva: Energoatomizdat, 1984. 152 p. (Rus)

4. Zahrivnyi E.A., Havrilov Yu.A. The method of excitation and regulation of autoreso-nance oscillation in the electric drive of the return-rotary motion. Patent RF No 2410826. 2009. (Rus)

5. Antonov A.E., Kyreyev V.G. Massage device. Patent UA 74668. 2006. (Ukr)

6. Akinin K.P., Kyreyev V.G., Filomenko A.A., Lavrinenko B.A., Mikhailik E.M. Re-search of electromechanical characteristics of brushless magnetoelectric motors of return-rotary motion. Pratsi Instytutu elektrodynamiky NAN Ukrainy. 2019. No 54. Pp. 47-51. (Rus)

7. Ivey K.A. AC carrier control systems. Moskva: Mashinostroenie, 1968. 320 p. (Rus)

8. Popovych M.G., Losynskyi O.Yu., Klepikov V.B. Electromechanical systems of the automatic control and electric drives. Kyiv: Lybid, 2005. 680 p. (Ukr)

9. Akinin K.P., Plugatar A.P. Regulators based on microcontrollers for electromechanical systems. Pratsi Instytutu elektrodynamiky NAN Ukrainy. 2010. No 27. Pp. 77-81. (Rus) 


\section{УДК 621.313 .8}

СИСТЕМА КЕРУВАННЯ ЗВОРОТНО-ОБЕРТАЛЬНИМ РУХОМ РОТОРА БЕЗКОНТАКТНОГО МАГНІТОЕЛЕКТРИЧНОГО ДВИГУНА

К.П. Акинін, докт. техн. наук, О.Є. Антонов, докт. техн. наук, В.Г. Кіреєв, канд. техн. наук, А.А. Філоменко Інститут електродинаміки НАН України, пр. Перемоги, 56, Київ, 03057, Україна

Описано систему керування зворотно-обертальним рухом ротора безконтактного магнітоелектричного двигуна. Досліджено метод розрахунку системи управління амплітудою кута повороту вала ротора на основі частотних характеристик розімкненої системи иляхом задання запасу стійкості за фазою. Розрахунок контуру обмеження діючого значення струму статорних обмоток проведено на підставі заданої точності такого обмеження. Використання отриманих аналітичних співвідношень дає змогу автоматично розраховувати параметри регуляторів залежно від значення частоти механічних коливань вала ротора в заданому робочому діапазоні. Наведено приклади розрахунку перехідних процесів регулювання амплітуди кута повороту і діючого значення струму при пуску двигуна і зміні механічного навантаження. Бібл. 9, рис. 5, табл. 3.

Ключові слова: безконтактний магнітоелектричний двигун, зворотно-обертальний рух, система керування, несуча частота, частотна характеристика.

УДК 621.313 .8

\section{СИСТЕМА УПРАВЛЕНИЯ ВОЗВРАТНО-ВРАЩАТЕЛЬНЫМ ДВИЖЕНИЕМ РОТОРА БЕСКОН- ТАКТНОГО МАГНИТОЭЛЕКТРИЧЕСКОГО ДВИГАТЕЛЯ}

К.П. Акинин, докт. техн. наук, А.Е. Антонов, докт. техн. наук, В.Г. Киреев, канд. техн. наук, А.А. Филоменко Институт электродинамики НАН Украины, пр. Победы, 56, Киев, 03057, Украина

Описана система управления возвратно-вращуательным движением ротора бесконтактного магнитоэлектрического двигателя. Исследован метод расчета системы управления амплитудой угла поворота вала ротора на основе частотных характеристик разомкнутой системы путем задания запаса устойчивости по фазе. Расчет контура ограничения действующего значения тока статорных обмоток проведен на основе заданной точности такого ограничения. Использование полученных аналитических соотношений позволяет автоматически рассчитывать параметры регуляторов в зависимости от значения частоть механических колебаний вала ротора в заданном рабочем диапазоне. Приведены примеры расчета переходных прочессов регулирования амплитуды угла поворота и действующего значения тока при пуске двигателя и изменении механической нагрузки. Библ. 9, рис. 5, табл. 3.

Ключевые слова: бесконтактный магнитоэлектрический двигатель, возвратно-вращательное движение, система управления, несущая частота, частотная характеристика. 